\title{
DOT-ELISA FOR THE DIAGNOSIS OF NEUROCYSTICERCOSIS
}

\author{
Rakhi BISWAS, S.C. PARIJA \& S.K. NARAYAN
}

\begin{abstract}
SUMMARY
The aim of the present study was to standardize and evaluate dot-Enzyme linked immunosorbent assay (Dot-ELISA), a simple and rapid test for the detection of cysticercus antibodies in the serum for the diagnosis of neurocysticercosis (NCC). The antigen used in the study was a complete homogenate of Cysticercus cellulosae cysts obtained from infected pigs and dotted on to nitrocellulose membrane. Test sera were collected from the patients of NCC, and control sera from patients with other diseases and healthy students and blood donors of the Jawaharlal Institute of Postgraduate Medical Education and Research (JIPMER) Hospital, Pondicherry, during a study period from 2001 to 2003. Dot-ELISA detected antibodies in 14 of 25 (56\%) in clinically suspected cases of NCC, 13 of $23(56.5 \%)$ in CT/MRI proven cases of NCC and 2 of $25(8 \%)$ each in non-cysticercal CNS infection controls and healthy controls. The test showed a sensitivity of $56.25 \%$, specificity of $92 \%$, positive predictive value of $87.09 \%$, and negative predictive value of $70.76 \%$. Results of the present study shows that the Dot-ELISA as a simple test can be used in the field or poorly equipped laboratories for diagnosis of NCC .
\end{abstract}

KEYWORDS: Neurocysticercosis; ELISA; Dot-ELISA; Cysticercus antigen.

\section{INTRODUCTION}

Neurocysticercosis (NCC) is an important parasitic disease of the human nervous system and constitutes a public health problem for most of the developing world ${ }^{23}$. It has been estimated that the NCC infects approximately 50 million people world-wide and cause at least 50,000 deaths annually ${ }^{2}$. The NCC is endemic in many parts of the world. Taeniasis/cysticercosis is of economic importance in several countries and regions, such as Mexico, Central and South America (except Uruguay and Argentina), Africa, India, Indonesia, Thailand and China ${ }^{10,27}$.In recent years, an increased incidence of NCC is being reported from America owing to an increase in immigration from endemic regions and also due to improved ease of diagnosis with the imaging techniques. It is common among Hispanic immigrants to the American South west ${ }^{4,26,28,31}$.

NCC is difficult to diagnose clinically because of its varied clinical presentation and non-specificity. Recently, immunological tests are being increasingly used in adjunct with imaging techniques to aid the diagnosis of NCC. Several immunological tests for demonstration of specific antibodies in the serum and cerebrospinal fluid (CSF) have been devised over the years. The first serological reaction for cysticercosis in the CSF was described by MOSES in the year $1911^{18}$. In most laboratories, indirect haemagglutination (IHA) ${ }^{12}$, enzyme-linked immunosorbent assay $(\text { ELISA })^{25}$, radioimmunoassay (RIA) ${ }^{16}$ and most recently the Western blot test ${ }^{34}$ are being used.
However, the test such as Western blot or plate ELISA although are specific and sensitive, have the disadvantages of being the tests that require expensive equipment, technical expertise, hence difficult to adapt in the field or in the not-so well equipped laboratories. Several authors have hence used dot-enzyme linked immunosorbent assay (Dot-ELISA), a simplified ELISA technique for detection of specific cysticercus antibodies in serum and CSF samples ${ }^{9,36,37}$. The aim of the present study was to standardize and evaluate dot-Enzyme linked immunosorbent assay (Dot-ELISA), a simple and rapid test for the detection of cysticercus antibodies in the serum for the diagnosis of neurocysticercosis in the less equipped laboratories or in the field situation.

\section{MATERIALS AND METHODS}

Patients and controls: Test sera were collected from the patients of neurocysticercosis (NCC), and control sera from patients with other diseases and healthy students and blood donors of the Jawaharlal Institute of Postgraduate Medical Education and Research (JIPMER) Hospital, Pondicherry, during a study period from 2001 to 2003.

The groups included:

Group 1 (strong clinical suspects of NCC): This group included 25 patients with single contrast enhancing ring lesions/single calcified nodular lesion of less than $0.5 \mathrm{~cm}$ diameter on CT Scan/MRI presenting 
with seizures, hydrocephalus or intracranial hypertension or psychiatric disturbances. This group comprises clinically strongly suspected cases of NCC, a well studied and well accepted clinical entity.

Group 2 (CT/MRI proven cases of NCC): This group included 23 patients with either CT Scan/MRI proven multiple contrast enhancing ring lesions of less than $0.5 \mathrm{~cm}$ diameter or multiple nodular calcified lesions of less than $0.5 \mathrm{~cm}$ diameter with or without meningoencephalitis. This group comprised clinico-radiologically definite cases of NCC.

Group 3 (Non-cysticercal CNS infection control): This group included 25 patients presenting with single/multiple margin enhancing lesions/calcified polymorphic lesions of more than $0.5 \mathrm{~cm}$ diameter with or without meningoencephalitis or microbiologically proven cases of tubercular or cryptococcal meningitis. This group comprised noncysticercus chronic meningoencephalitis and thus formed an important control group of other infectious diseases.

Group 4 (Healthy controls): This group included 25 healthy adults (blood donors and students) who had not suffered from cysticercosis or any other disease during the study period from 2001 to 2003.

The informed consent was obtained from all human adult participants and from parents or legal guardians of minors. The project was approved by the JIPMER research council.

Serum: Serum samples were collected from all the patients and controls described earlier. Five milliliters of venous blood was also collected from each patient under aseptic precautions and was allowed to clot. The serum was separated and preserved with $0.05 \mathrm{~mol} / \mathrm{L}$ sodium azide and stored at $-20^{\circ} \mathrm{C}$ until used.

Preparation of cysticercus antigen: Preparation of $C$. cellulosae porcine complete homogenate antigen was carried out according to the method described by SREENIVASAMURTHY et al..$^{32}$. In this procedure, approximately 100 cysts that were dissected free from pork tissue were washed thrice in PBS ( $\mathrm{pH}$ 7.2) to remove extraneous matter. The cysts were homogenized in a glass tissue homogenizer with PBS ( $\mathrm{pH} 7.2$ ) containing $0.1 \mathrm{mM}$ phenyl methyl sulphonyl fluoride (PMSF). Homogenization was done under cooling condition. The homogenized tissue suspension was then sonicated eight times at $12 \mathrm{KHz}$ with 30 seconds cooling interval. Each cycle of sonication was for one minute and it was done again under cooling condition in an ice bath. The sonicated material was centrifuged at $40{ }^{\circ} \mathrm{C}$ for 30 minutes at 14,000 $\mathrm{rpm}$. The supernatant was collected as the complete homogenate antigen, aliquoted to $1 \mathrm{ml}$ cryoprotected vials and stored at $-20{ }^{\circ} \mathrm{C}$.

Detection of cysticercus antibodies in the serum: The circulating cysticercus antibodies were detected in the serum by a plate ELISA and Dot-ELISA.

Plate-enzyme linked immunosorbent assay (ELISA): The presence of cysticercus antibodies in the patient's serum was also detected by a commercially available plate ELISA kit marketed with the brand name UBI, MAGIWEL enzyme immunoassay-cysticercosis (Germany). The tests were carried out according to manufacturer's instructions. Result was noted as per the instructions provided along with the kit.
Dot-enzyme linked immunosorbent assay (Dot - ELISA): The DotELISA depends upon the principle that when test serum is layered on the nitrocellulose membrane bound with the cysticercus antigen, the specific cysticercus antibodies, if present in the serum, will bind to the cysticercus antigen dot. This binding reaction is detected visually by addition of an enzyme-labeled second antibody and subsequent development of the label antibody.

Dot-ELISA was standardized to detect cysticercus antibodies in the serum of NCC patients.

The procedure consists of the following steps:

(i) $2 \mu \mathrm{l}$ of complete homogenate $(\mathrm{CH})$ porcine cysticercus antigen of $0.72 \mathrm{~g} \%$ was added to square sized nitrocellulose membrane pasted on plastic strips $(3 \mathrm{~cm} \times 0.5 \mathrm{~cm})$. The strips with the antigen were air dried for 30 minutes to 45 minutes. The antigen in the strips was then blocked with a diluent (2\% BSA in PBS, $\mathrm{pH} 7.2)$ for three hours over a shaker. Washing of the strips was done three times with $0.1 \%$ Tween 20 in PBS ( $\mathrm{pH} 7.2$ ) over a period of 15 minutes.

(ii) The strips were incubated at room temperature with $2 \mu$ of patients serum diluted with $20 \mu \mathrm{l}$ of $0.1 \%$ Tween 20 in PBS ( $\mathrm{pH} 7.2$ ), for 90 minutes with continuous shaking.

(iii) Washing of the strips was then repeated three times. Then commercially available rabbit antihuman $\mathrm{IgG}$ peroxidase conjugate marketed by BANGALORE GENEI, INDIA was added as (1:1000 dilutions in PBS Tween 20) and incubated for 30 minutes over the shaker. Again washing was repeated three times.

(iv) Then $5 \mathrm{mg}$ of diaminobenzidine substrate in $5 \mathrm{ml}$ of PBS Tween 20 (1:1000 dilutions) was added to the strips followed by $5 \mu$ of hydrogen peroxide. The strips were then incubated for 10 minutes in the dark.

(v) Reaction was stopped with distilled water and the results were read immediately. The results were read as development of a deep reddish brown coloured dot in nitrocellulose membrane was considered as reactive, where as colourless dot was considered as non-reactive.

Statistical analysis of the immunoassays: The statistical analysis was carried out using Epi Info package supplied by the WHO.

The serum samples were tested in a single blind manner. The sources of the specimen (whether they were from the patients or from control subjects) were not known to those performing the different tests with these specimens. The sensitivity, specificity, positive predictive valve, and negative predictive valve of the tests were calculated according to the method described by GALEN \& GAMBINO 6 .

\section{RESULTS}

Dot-ELISA: The serum samples, which showed development of brick red coloured dot on nitrocellulose membrane, were considered reactive. The cysticercus antibodies could be demonstrated by Dot-ELISA in the sera of different groups of NCC and controls. Dot-ELISA detected antibodies in 14 of $25(56 \%)$ in clinically suspected cases of NCC, 13 of 
$23(56.5 \%)$ in CT/MRI proven cases of NCC and 2 of $25(8 \%)$ each in non-cysticercal CNS infection controls and healthy controls.

The sensitivity, specificity, positive predictive value and negative predictive value of the tests by Dot-ELISA were found to be $56.25 \%$, $92 \%, 87.09 \%$ and $68.66 \%$ respectively.

Plate ELISA: Commercial microtitre plate ELISA demonstrated a positivity of 9 of $25(36 \%)$ in clinically suspected cases of NCC, 12 of $23(52.1 \%)$ in CT/MRI proven cases of NCC and 1 of $25(4 \%)$ in healthy controls. However, no antibodies were detected in serum of noncysticercal CNS infection controls.

The sensitivity, specificity, positive predictive value and negative predictive value of the tests by Plate ELISA were found to be $43.75 \%$, $98 \%, 95.45 \%$ and $64.4 \%$ respectively.

\section{DISCUSSION}

In India, the NCC has been reported widely from different parts of the country as Delhi ${ }^{1}$, Uttaranchal region ${ }^{35}$, Chandigarh ${ }^{14}$, Pondicherry $^{33,38}$. Before the advent of CT/MR era, the frequency of NCC as a cause of epilepsy in India was reported to vary from $2.2 \%$ to $9.6 \%{ }^{11,15}$. After the availability of CT/MR imaging, NCC has been found to be the cause in $9 \%$ to $18.6 \%$ of patients with epilepsy ${ }^{7,8}$. Varied reports are available regarding the role of NCC in intracranial space occupying lesion. While some workers report that $1 \%$ of intracranial spaceoccupying lesions in children in India are accounted for by parasites ${ }^{22}$, others show that $17.4 \%-29.2 \%$ of cases of intracranial space occupying lesions and epilepsy are due to cysticercosis ${ }^{10}$. In Bangalore, approximately $26 \%$ of the space-occupying sessions of the CNS were found to be caused by cysticercosis ${ }^{13}$. In JIPMER, Pondicherry a total of 21 childhood neurocysticercosis was reported over five years from 1984 to $1989^{33}$.

Demonstration of specific antibodies in the serum is the most common approach for the diagnosis of parasitic diseases. A number of serological tests have been evaluated and used for the detection of specific antibodies in the serum with variable results in the diagnosis of NCC.

The ELISA and EITB are the most frequently used antibody-based tests for the detection of antibodies in the serum ${ }^{5}$. ELISA and EITB were used to detect serum $\mathrm{IgG}$ antibodies to Taenia solium metacestodes ${ }^{17,29}$ while ELISA also measured IgM antibodies against Cysticercus antigen in both serum and CSF samples of patients with active $\mathrm{NCC}^{25}$. The ELISA has been used widely by various authors for the detection of cysticercus antibodies in the serum with variable sensitivities of $50 \%{ }^{25}, 10.4 \%{ }^{17}, 79 \%^{3}$ and $93 \%$ and specificities of $70 \%{ }^{25}$ and $93 \%^{30}$ for the diagnosis of NCC. Also the ELISA test demonstrated cross reactions with other parasitic diseases as hydatid disease, schistosomiasis and angiostrongyliasis ${ }^{3,17}$. In the present study, the plate ELISA showed a low sensitivity of $43.75 \%$ but a high specificity of $98 \%$.

Dot-ELISA, developed as a modification of the ELISA using nitrocellulose membrane as a carrier of protein, has become increasingly popular as a field test for the diagnosis of many parasitic diseases such as visceral leishmaniasis ${ }^{19,20}$, malaria, schistosomiasis mansoni and fascioliasis $^{21}$ and cystic echinococcosis ${ }^{24}$.
Dot-ELISA has also been employed in NCC for the detection of cysticercus antibodies in the serum as well as in the $\mathrm{CSF}^{9,36,37}$. A preliminary study conducted on CSF samples for the presence of specific cysticercus antibodies, with the cysticercus antigen dotted on a new solid phase of synthetic polyester fabric impregnated with a polymerized resin, revealed, 14 out of $15 \mathrm{CSF}$ samples of NCC to have titres ranging from one to $128^{36}$. Another study on CSF samples for cysticercus antibody detection, by Dot-ELISA showed sensitivity and specificity of $95.1 \%$ and $90.6 \%$ respectively for $C$. cellulosae antigen, while showed a sensitivity of $97.6 \%$ for Cysticercus longicollis antigen and specificities of $96.9 \%$ for the membrane - C. longicollis $(\mathrm{M}-\mathrm{Cl})$ antigen and $100 \%$ for the vesicular fluid $-C$. longicollis $(\mathrm{VF}-\mathrm{Cl})$ antigen ${ }^{37}$. For testing serum samples for specific cysticercus antibodies in patients with NCC, Dot-immunogold-silver staining (Dot-IGSS) and Dot-ELISA using $T$. solium antigen have been compared. The average titre of the sera detected by Dot-IGSS was 1:27,470, which was significantly higher than that detected by Dot-ELISA ${ }^{9}$. In the present study, Dot-ELISA using the complete homogenate antigen of T. solium, tested only on serum samples for specific cysticercus antibodies was found to be only $56.25 \%$ sensitive and $92 \%$ specific for diagnosis of NCC. Although the test is of moderate sensitivity, it has potential for wider use for diagnosis of NCC, specially in the field or in poorly equipped laboratories in the absence of imaging facilities such as CT and MR which are highly expensive.

Dot-ELISA as a test for use in the field or poorly equipped laboratories for the diagnosis of NCC offers many advantages. The foremost advantage is that the test is a rapid test, is easy to perform and the results are read visually, eliminating the need for an ELISA reader. Second, the test can be carried out by imparting minimal basic training to locally available technical staff and, it is easy to use. Third, nitrocellulose binds more antigens than microtitre plates. Finally the test is inexpensive because the cost of nitrocellulose membrane is less than that of microtitre plates.

\section{RESUMO}

\section{Dot-ELISA no diagnóstico da neurocisticercose}

O objetivo do presente estudo foi estandardizar e avaliar o DotELISA, um teste simples e rápido para detectar anticorpos de cisticercos no soro para diagnóstico da neurocisticercose (NCC). O antígeno usado no estudo foi um homogenizado completo de cistos de Cysticercus cellulosae obtidos de porcos infectados e marcados sobre a membrana de nitrocelulose. Os soros testados foram coletados de pacientes com NCC e os soros controle de pacientes com outras doenças e estudantes saudáveis e doadores e sangue do "Jawaharlal Institute of Postgraduate Medical Education and Research Hospital", em Pondicherry, durante o período de estudo de 2001 a 2003. Dot-Elisa detectou anticorpos em 14 de $25(56 \%)$ casos suspeitos de NCC, em 13 de 23 (56,5\%) em CT/MRI casos provados de NCC e em 2 de $25(8 \%)$ cada em controles de infecções do sistema nervoso não devidas à cisticercose e controles saudáveis. $\mathrm{O}$ teste mostrou sensibilidade de $56,25 \%$, especificidade de $92 \%$, valor preditivo positivo de $87,09 \%$ e valor preditivo negativo de $70,76 \%$. Resultados do presente estudo mostram que o Dot-ELISA como teste simples pode ser usado em trabalhos de campo ou em laboratórios pobremente equipados para o diagnóstico da NCC. 


\section{REFERENCES}

1. AGARWAL, V.; KUMAR, P. \& CHADDA, R.K. - Neurocysticercosis presenting as a psychiatric illness. Indian J. Pediat., 68: 1073-1074, 2001.

2. ANONYMOUS - Centers for Disease Control: locally acquired neurocysticercosis, North Carolina, Massachusetts and South Carolina, 1989-1991. M. M. W. R., 41: 1, 1992.

3. DIWAN, A.R.; COKER-VANA, M.; BROWN, P. et al. - Enzyme-linked immunosorbent assay (ELISA) for the detection of antibody to cysticerci of Taenia solium. Amer. J. trop. Med. Hyg., 31: 364-369, 1982.

4. EARNEST, M.P.; RELLER, L.B.; FILLEY, C.M. \& GREK, A.J. - Neurocysticercosis in the United States: 35 cases and a review. Rev. infect. Dis., 9: 961-979, 1987.

5. EOM, K.S.; CHO, S.Y. \& RIM, J.H. - Comparative evaluation of indirect immunofluorescent antibody test with ELISA in serodiagnosis of human neurocysticercosis. Kisaengchunghak Chapchi, 26: 27-32, 1988.

6. GALEN, R.S. \& GAMBINO, S.R. - Beyond normality: the predictive value and efficiency of medical diagnosis. New York, John Wiley, 1975. p. 30-40.

7. GUPTA, R.S. \& MEENA, V.R. - Neurocysticercosis. In: PROCEEDINGS OF NEUROLOGY - UPDATE, New Delhi, GB Pant Hospital, 1989. p. 34-54.

8. KUMAR, R. - Abnormal CT scans in patients with late onset seizures with special reference to disappearing lesions. Bombay, 1990. (Dissertation - University of Bombay).

9. LIU, Y.S.; DU, W.P. \& WU, Z.X. - Dot-immunogold-silver staining in the diagnosis of cysticercosis. Int. J. Parasit., 26: 127-129, 1996.

10. MAHAJAN, R.C. - Geographical distribution of human cysticercosis: In: FLISSER, A.; WILliAMS, K.; LACLETTE, J.P. et al., ed. Cysticercosis: present state of knowledge and prospective. New York, Academic Press, 1982. p. 39-46.

11. MAHAJAN, R.C. \& CHOPRA, J.S. - Cysticercosis amongst cases of epilepsy and intracranial space occupying lesion. In: PROCEEDINGS OF NATIONAL SEMINAR ON EPILEPSY, Bangalore, India, 1975. p. 95-97.

12. MAHAJAN, R.C.; CHOPRA, J.S. \& CHITKARA, N.L. - Comparative evaluation of indirect haemagglutination and complement fixation tests in serodiagnosis of cysticercosis. Indian J. med. Res., 63: 121-125, 1975.

13. MAITI, B. - Neurocysticercosis, an update. J. Ass. Phycns. India, 43: 477-482, 1995.

14. MALlA, N. \& MAHAJAN, R.C. - Human Neurocysticercosis. In: SOOD, M.L., ed. Helminthology in India. New Delhi, IBD Publ., 2003. p. 247-262.

15. MANI, A.J.; RAMESH, C.A.; AHUJA, G.K. \& MANI, K.S. - Cerebral cysticercosis presenting as epilepsy. Neurology (India), 22: 30-34, 1974.

16. MILLER, B.; GOLDBERG, M.A.; HEINER, D.; MYERS, A. \& GOLDBERG, A. - A new immunologic test for CNS cysticercosis. Neurology, 34: 695-697, 1984.

17. MITTAL, V.; SINGH, V.K. \& ICHHAPUJANI, R.L. - Detection of antibodies to Taenia solium in sera of patient with epilepsy using ELISA. J. Communicat. Disor., 33: 23-27, 2001.

18. MOSES, A. - Dos metodos biolojicos de diagnostico nas cisticercozes. Mem. Inst. Oswaldo Cruz, 3: 320-327, 1911.

19. PAPPAS, M.G.; HAJKOWSKI, R. \& HOCKMEYER, W.T. - Dot enzyme-linked immunosorbent assay (Dot-ELISA) a micro technique for the rapid diagnosis of visceral leishmaniasis. J. immunol. Meth., 64: 205-214, 1983.

20. PAPPAS, M.G.; HAJKOWSKI, R.; CANNON, L.T. \& HOCKMEYER, W.T. - Dot enzyme-linked immunosorbent assay (Dot-ELISA) comparison with standard ELISA and complement fixation assays for the diagnosis of human visceral leishmaniasis. Vet. Parasit., 14: 239-249, 1984.
21. PARIJA, S.C. - Textbook of medical Parasitology. Madras, AIPD, 2004. p. 205-235.

22. REDDY, D.R. \& MURTHY, J.M. - Parasitic intracranial space occupying lesions in children in India. Child Nervous System, 2: 244-247, 1986.

23. ROMAN, G.; SOTElO, J.; DEL BRUTTO, O. et al. - A proposal to declare neurocysticercosis an international reportable disease. Bull. Wld. Hlth. Org., 78: 399-406, 2000.

24. ROMIA, S.A.; YOUSSEF, M.E.; HANDOUSSA, A.E.; RIZK, H.M. \& SALLAM, S.M - Dot-ELISA as a diagnostic test in hydatid disease. J. Egypt. Soc. Parasit., 22: 603-610, 1992.

25. ROSAS, H.; SOTELO, J. \& NIETO, D. - ELISA in diagnosis of neurocysticercosis. Arch. Neurol., 43: 353-356, 1986.

26. ROSENFELD, E.A.; BYRD, S.E. \& SHULMAN, S.T. - Neurocysticercosis among children in Chicago. Clin. infect. Dis., 23: 262-268, 1996.

27. SCHANTZ, P.M.; CRUZ, M.; SARTI, E. \& PAWLOSKI, Z.S. - The potential eradicability of taeniasis and cysticercosis. Bull. Pan Amer. HIth. Org., 27: 397-403, 1993

28. SHANDERA, W.X.; WHITE Jr., A.C.; CHEN, J.; DIAZ, P. \& ARMSTRONG, R. Cysticercosis in Houston, Texas: a report of 112 cases. Clin. infect. Dis., 24 : 101 115, 1994.

29. SHIGUEKAWA, K.Y.; MINEO, J.R.; de MOURA, L.P. \& COSTA-CRUZ, J.M. - ELISA and Western blotting tests in detection of IgG antibodies to Taenia solium metacestodes in serum samples in human neurocysticercosis. Trop. Med. Int. HIth., 5: 443-449, 2000 .

30. SLOAN, L.; SCHNEIDER, S. \& RISENBLATT, J. - Evaluation of enzyme-linked immunoassay for serological diagnosis of cysticercosis. J. clin. Microbiol., 33: 3124 3128, 1995.

31. SORVILLO, F.J.; WATERMAN, S.H.; RICHARDS, F.O. \& SCHANTZ, P.M. Cysticercosis surveillance: locally acquired and travel related infection and detection of intestinal tapeworm carriers in Los Angeles county. Amer. J. trop. Med. Hyg., 47: 365-371, 1992.

32. SREENIVASAMURTHY, G.S.; D'SOUZA, P.E. \& JAGANNATH, M.S. - Enzyme linked immunoelectro transfer blot in the diagnosis of Taenia solium cysticercosis in pigs. J. Parasitic Dis., 23: 85-88, 1999.

33. THAKUR, L.C. \& ANAND, K.S. - Childhood neurocysticercosis in South India. Indian J. Pediat., 58: 815-819, 1991

34. TSANG, V.C.W.; BRAND, J.A. \& BOYER, A.E. - An enzyme linked immunoelectrotransfer blot assay and glycoprotein antigens for diagnosing human cysticercosis (Taenia solium). J. infect. Dis., 59: 50-59, 1989.

35. VARMA, A. \& GAUR, K.J. - The clinical spectrum of neurocysticercosis in the Uttaranchal region. J. Ass. Phycns India, 50: 1398-1400, 2002.

36. VAZ, A.J.; FERREIRA, A.W.; CAMARGO, M.E.; NAKAMURA, P.M. \& CAMARGO, E.D. - Dot-ELISA for detection of anti Cysticercus cellulosae antibodies in human cerebrospinal fluid using a new solid-phase (resin treated polyester fabrics). Preliminary report. Rev. Inst. Med. trop. S. Paulo, 32: 355-359, 1990.

37. VAZ, A.J.; NAKAMURA, P.M.; CAMARGO, M.E.; CAMARGO, E.D. \& FERREIRA, A.W. - Dot-ELISA for the detection of anti-Cysticercus cellulosae antibodies in cerebrospinal fluid using a new solid phase (resin-treated polyester fabric) and Cysticercus longicollis antigens. Rev. Inst. Med. trop. S. Paulo, 38: 391-396, 1996.

38. VELIATH, A.J.; RATNAKAR, C. \& THAKUR, L.C. - Cysticercosis in South India. J. trop. Med. Hyg., 88: 25-29, 1985.

Received: 22 June 2004

Accepted: 16 August 2004 